\title{
Meningkatkan Pengetahuan Siswa Tentang Sistem Persamaan Linear Dua Variabel (SPLDV) Melalui Model Pembelajaran Kooperatif
}

\author{
Dwi Risky Arifanti, Sumardin Raupu, St Zuhaerah Thalha
}

How to cite : Arifanti, D.R., Raupu, S., Thalha, S.Z, 2021. Meningkatkan Pengetahuan Siswa Tentang Sistem Persamaan Linear Dua Variabel (SPLDV) Melalui Model Pembelajaran Kooperatif. Kognitif: Jurnal Riset HOTS Pendidikan Matematika. 1(1). 22-33. https://doi.org/10.51574/kognitif.v1i1.8

To link to this article : https://doi.org/10.51574/kognitif.v1i1.8

Opened Access Article

Published Online on 1 Juni 2021

$\underline{\text { Submit your paper to this journal }}$ 


\title{
Meningkatkan Pengetahuan Siswa Tentang Sistem Persamaan Linear Dua Variabel (SPLDV) Melalui Model Pembelajaran Kooperatif
}

\author{
Dwi Risky Arifanti ${ }^{*}$, Sumardin Raupu ${ }^{1}$, St. Zuhaerah Thalha ${ }^{1}$ \\ Program Studi Tadris Matematika, Fakultas Tarbiyah dan Ilmu Keguruan, Institut Agama Islam \\ Negeri Palopo
}

\begin{tabular}{l}
\hline Article Info \\
\hline Article history: \\
Received Mar 6, 2021 \\
Accepted Apr 29, 2021 \\
Published Online Juni 1, 2021
\end{tabular}

\section{Keywords:}

Pembelajaran kooperatif Persamaan linear dua

Penelitian tindakan

Pengetahuan siswa

\begin{abstract}
Sejumlah permasalahan dalam Sistem Persamaan Linear Dua Variabel (SPLDV), mendorong para peneliti melakukan kajian yang beragam. Namun, masih sedikit peneliti yang mengintegrasikan antara model pembelajaran dengan materi tersebut. Oleh karena itu, penelitian ini bertujuan untuk mendeskripsikan bagaimana peningkatan pengetahuan SPLDV siswa melalaui pembelajaran kooperatif. Kami melakukan Penelitian tindakan kelas bersama dengan guru di kelas atau dilokasi penelitian dengan melibatkan siswa di tingkat menengah. Data yang dikumpulkan berupa observasi, tes, dan dokumentasi. Kami menggunakan analisa kuantitatif dan kualitatif untuk mendeskripsikan temuan. Dari hasil tersebut, kami menemukan bahwa terjadi peningkatan pengetahuan siswa tentang SPLDV melalui model kooperatif. Lebih lanjut, peningkatan ini berdampak pada peningkatan aktivitas guru dan siswa dalam kelas serta meminimalkan kesalahan siswa dalam menyelesaikan masalah SPLD
\end{abstract}

Copyright $\odot 2021$ Kognitif. All rights reserved.

\section{Corresponding Author:}

Dwi Risky Arifanti,

Program Studi Tadris Matematika,

Fakultas Tarbiah dan Ilmu Keguruan,

Institut Agama Islam Negeri Palopo,

Email: dwi_risky_arifanti@iainpalopo.ac.id

\section{Pendahuluan}

Teori pembelajaran berkembang dari waktu ke waktu sebagai fenomena yang menarik untuk diperhatikan. Dengan cara ini ide-ide awal dapat diperkaya dan menjadi bagian yang lebih komprehensif. Dalam makalah ini, data spesifik dalam persamaan linier dan transisi ke persamaan kuadrat akan ditempatkan dalam kerangka kerja yang lebih luas untuk perkembangan kognitif yang menyatukan beberapa untaian penelitian yang berbeda dalam satu teori.

Beberapa penelitian mengemukakan bahwa persamaan seperti $3 x-1=5$ mengekspresikan suatu nilai dikalikan dengan 3 dan dikurangi 1 menghasilkan 5. Dengan cara 
berpikir terbalik, siswa cenderung menyadari bahwa nilai yang dicari adalah 5 dijumlahkan 1 untuk mendapatkan $3 x=6$, kemudian 6 dibagi dengan 3 untuk mendapatkan jawaban $x=2$ (Filloy et al., 2010). Sedangkan, persamaan $3 x+2=x+6$ tidak dapat diselesaikan dengan membongkar proses aritmatikanya, namun mereka membutuhkan operasi aljabar untuk menyederhanakan persamaan tersebut untuk memperoleh penyelesaian (Tall et al., 2014). Ini menunjukkan bahwa ada suatu informasi yang perlu dipahami siswa dengan memaknai tanda "sama dengan" sebagai operasi yang muncul dari pengalaman aritmatika dimana bentuk $3+$ $4=7$ dipandang sebagai operasi sederhana untuk menjumlahan tiga objek dengan empat objek untuk mendapatkan tujuh, karena itu persamaan $3 x-1=5$ dilihat sebagai operasi yang mungkin diselesaikan dengan membongkar proses aritmatikanya (Blanton et al., 2018).

Lima \& Tall (2008) mengklasifikasi persamaan bentuk aljabar bentuk "persamaan = angka" sebagai bentuk evaluasi karena melibatkan bilangan numerik dari ekspresi aljabar, dimana nilai input $x$ dapat ditemukan dengan "membongkar" atau memanipulasi bentuk aljabar untuk memperoleh penyelesaiannya. Disisi lainnya, jika solusi persamaan linear melibatkan konsep kesamaan yang direalisasikan secara konseptual, maka siswa justru mengalami kesulitan dengan kasus itu (Soneira et al., 2018). Persamaan $3 x+2=x+6$ dapat dengan mudah diselesaikan dengan konsep keseimbangan dengan membayangkan $x$ sebagai objek yang tidak diketahui dengan berat yang sama dan mereprsentasikan persamaannya dengan $3 x$ dan 2 disebelah kiri dan $x$ dan 6 disebelah kanan. Kemudian, memungkinkan untuk memindahkan 2 dari kedua sisi untuk tetap mempertahankan keseimbangan menjadi $3 x=x+$ 4 kemudian menghilangkan $x$ dari kedua sisi untuk memperoleh $2 x=4$, hingga diperoleh $x=$ 2. Tall et al (2014) menyebut kondisi ini sebagai model kesetimbangan untuk kasus persamaan linear satu variabel. Namun, hal ini menjadi kasus tersendiri untuk pengurangan, maka untuk merealkan situasinya cukup rumit, misalkan dengan mengambil 1 jika nilai $x$ tidak diketahui. Maka persamaan $3 x-1=5$ tidak dapat direpresentasikan secara langsung dengan model keseimbangan karena ruas kiri $3 x-1$ tidak dapat dipandang sebagai $3 x$.

Dari data Lima \& Tall (2008) menyajikan hasil kerja siswa tentang persamaan linear yang tidak sesuai dengan model keseimbangan. Hal ini dikarenakan guru mereka menggunakan pandangan mengajar konvensional dan memperkenalkan strategi penyelesaian yang sifatnya umum untuk menyederhanakan persamaan. Sebaliknya, siswa lebih fokus pada tindakan dengan mengubah simbol hingga menghasilkan solusi. Mereka biasa menggunakan strategi menukar posisi dan tanda untuk mendapat jawaban, misalkan $3 x-1=3+1$ menjadi $3 x-$ $x=3+1$. Hingga melibatkan strategi bertukar posisi dan menempatkannya sebagai pembagian, misalkan $2 x=4$ menjadi $x=\frac{4}{2}$. Namun, berbeda dengan Sistem Persamaan Linear Dua Variabel (SPLDV), dimana siswa tidak lagi memanfaatkan model kesetimbangan atau menukar posisi/tanda untuk memperoleh solusi. Dimana mereka perlu mengembangkan idenya untuk menggunakan strategi eliminasi, substitusi, invers untuk menemukan penyelesaiannya (Harel, 2017).

Beragam kesulitan yang dialami siswa ketika menghadapi masalah yang berkaitan dengan SPLDV. Kesulitan dengan tanda sama dengan prosedur standar dalam aljabar (Hewitt, 2012), menganalisa hubungan antar variabel dengan menggunakan pemikiran fungsional (Wilkie, 2016), menerapkan aturan untuk memperoleh nilai setiap variabel (Fonger, 2019). Ciri keabstrakan masalah SPLDV menyebabkan siswaa tidak memahami alur penyelesaiannya. Ini berarti perlu adanya "jembatan" yang dapat meminimalkan kesulitan siswa dalam proses pembelajaran. Dalam pelaksanaan pembelajaran, guru dituntut lebih kreatif dan inisiatif dalam upaya mengembangkan potensi siswa sehingga pembelajaran tersebut menjadi optimal hingga mereka memahami konsep pada SPLDV. Salah satu pembelajaran yang harus mendapatkan perhatian adalah model pembelajaran kooperatif. Dimana guru memberikan apersepsi awal, membentuk kelompok belajar, menstimulasi terjadinya diskusi, dan tanya jawab antara siswa 
dan guru. Hal ini menjadi perlu dipertimbangkan untuk meningkatkan pengetahuan siswa tentang SPLD.

Singkatnya, penelitian ini relevan dan perlu mengingat hal-hal berikut: (1) peningkatan pengetahuan siswa melalui pembelajaran adalah tema terkini dalam program penelitian pendidikan matematika; (2) kajian tentang peningkatan pengetahuan SPLDV melalui pembelajaran kooperatif harus dipromosikan di kelas sesuai dengan kurikulum; dan (3) penelitian ini memberikan informasi yang relevan untuk memahami SPLDV yang dapat dibuat oleh siswa dan dapat berfungsi sebagai kerangka teoritis. Jadi, penelitian ini memiliki dua kontribusi untuk bidang pendidikan matematika: pertama, memberikan kerangka kerja untuk mempelajari pembelajaran kooperatif bagaimana yang mampu meningkatkan pengetahuan SPLDV siswa. Kedua, ini menunjukkan pentingnya mensintesis antara materi dan model pembelajaran dengan melibatkan tugas matematika.

Oleh karena itu, dalam makalah ini, kami mengusulkan untuk menjawab pertanyaan penelitian berikut:

"Bagaimana peningkatan pengetahuan SPLDV siswa melalaui pembelajaran kooperatif?"

\section{Metode}

Jenis penelitian yang digunakan adalah jenis penelitan tindakan kelas (classroom action research) karena penelitian ini terlibat langsung dalam proses belajar mengajar mulai dari awal sampai akhir pelajaran. Penelitian tindakan kelas ini dilakukan oleh peneliti langsung bersama dengan guru di kelas atau dilokasi penelitian.Secara sederhana penelitian tindakan kelas atau classroom action research dapat diartikan sebagai kegiatan penelitian untuk mendapatkan kebenaran dan manfaat praktis dengan cara melakukan tindakan secara kolaboratif dan partisipatif. Kolaborasi adalah adanya kerjasama antara berbagai disiplin ilmu, keahlian dan profesi dalam memecahkan masalah, merencanakan, melaksanakan kegiatan, dan melakukan penilaian akhir. Disini kolaborasi menjadi hal yang sangat penting dalam penelitian tindakan kelas (PTK). Sebab salah satu ciri khas PTK adalah adanya kolaborasi atau kerjasama antara praktisi dan peneliti dalam pemahaman, kesepakatan tentang permasalahan, pengambilan keputusan yang akhirnya melahirkan tindakan (action). ${ }^{1}$ Pada penelitian ini ada empat tahapan pelaksanaan yaitu perencanaan (Planning), tindakan (Action), obsevasi (Observation), dan refleksi (Reflection) sebanyak dua siklus.

\section{Partisipan}

Penelitian ini dilaksanakan di Sekolah Menengah yang beradar di Wilayah Tenga Indonesia. Sebanyak 31 siswa yang berpartisipasi dalam penelitian ini, dimana 16 diantaranya adalah siswa laki-laki dan 15 diantaranya siswa perempuan dan berusia 13-14 tahun.

\section{Pengumpulan Data}

Pengumpulan data berupa: pertama, observasi, dimana hasil yang ingin dicapai dilihat dari hasil observasi yang dilakukan guru maupun peneliti pada saat proses belajar mengajar berlangsung tentunya dengan berpatokan pada indikator-indikator pencapaian yang diinginkan. Kedua, tes, dimana data mengenai peningkatan hasil belajar matematika siswa diambil dari tes pada setiap akhir siklus, tesnya berbentuk essay. Ketiga, dokumentasi, berupa foto dan data nilai yang digunakan untuk menggambarkan secara visual kondisi yang terjadi saat pembelajaran berlangsung. 


\section{Analisis Data}

Data yang diperoleh dalam penelitian ini akan dianalisis secara kuantitatif dan kualitatif. Untuk data hasil tes siswa dianalisis menggunakan analisis kuantitatif digunakan statistik deskriptif yaitu nilai rata-rata, frekuensi, nilai rendah, dan nilai tinggi yan diperoleh melalui SPSS. Sedangkan untuk lembar hasil observasi guru dan siswa dianalisis secara kualitatif. Pertama dilakukan analisis Kevalidan Instrument Penelitian. Validitas berkenaan dengan ketepatan alat ukur terhadap konsep yang diukur, sehingga mengukur apa yang seharusnya diukur. Kedua, analisis nilai reliabilitas instrumen penelitian yang digunakan diperoleh dari lembar penilaian yang telah diisi oleh tiga validator. Ketiga, analisis aktivitas guru dan siswa selama kegiatan proses pembelajaran berlangsung dianalisis dan dideskripsikan. Ketiga, analisis tes hasil belajar matematika dengan menganalisa statistik deskriptif yaitu nilai rata-rata, frekuensi, nilai rendah, dan nilai tinggi yang diperoleh siswa.

\section{Siklus Penelitian}

Penelitian tindakan kelas ini dilaksanakan dua siklus dimana 2 kali tatap muka dan 1 kali evaluasi pada setiap siklus. Kegiatan setiap siklusnya dimulai dari perencanaan, pelaksanaan, pengamatan, dan refleksi yang akan diuraikan sebagai berikut:

\section{Gambaran Siklus I}

Siklus I dilaksanakan selama 3 kali pertemuan dengan 2 kali tatap muka dan satu kali evaluasi. Berdasarkan prosedur penelitian tindakan kelas, maka yang dilakukan pada siklus I sebagai berikut. Pertama, Tahap Perencanaan: (1) Melakukan observasi di kelas; Melakukan konsultasi dengan dosen pembimbing dengan guru mata pelajaran yang bersangkutan mengenai rencana teknis penelitian; (3) Menentukan materi yang akan diajarkan; (4) Membuat rencana pembelajaran (RPP) dengan menggunakan model kooperatif; (5) Membuat format observasi untuk mengamati kondisi pembelajaran di kelas ketika pelaksanaan tindakan kelas sedang berlangsung, seperti: daftar hadir dan keaktifan siswa di dalam proses belajar mengajar; (6) Membuat dan menyusun alat evaluasi. Kedua, Tahap Pelaksanaan: (1) Peneliti menentukan tujuan-tujuan pembelajaran yang ingin dicapai; (2) Peneliti menjelaskan materi sesuai dengan rencana pengajaran pada awal pertemuan yang berlangsung secara klasikal kurang lebih 15 menit; (3) Membentuk kelompok besar; (4) Peneliti memilih pemimpin dari kelompok besar tersebut; (5) Tahap diskusi kelompok kecil; (6) Membentuk kelomok kecil dari masing-masing kelompok besar tersebut; (7) Guru memberikan permasalahan pada kelompok kecil untuk didiskusikan sesuai waktu yang telah ditentukan; dan (8) tahap diskusi kelas. Ketiga, Tahap Observasi, pada tahap ini dilakukan proses observasi selama kegiatan pembelajaran berlangsung. Pada akhir siklus diadakan tes tertulis untuk mengukur peningkatan hasil belajar selama siklus I. Keempat, Tahap Refleksi, merefleksi setiap hal yang diperoleh melalui lembar observasi, menilai dan mempelajari perkembangan hasil pekerjaan siswa pada akhir siklus I. Dari kedua hasil inilah yang selanjutnya dijadikan acuan bagi penulis untuk merencanakan perbaikan dan penyempurnaan siklus berikutnya (siklus II) sehingga hasil yang dicapai lebih baik dari siklus sebelumnya.

\section{Gambaran Siklus II}

Langkah-langkah yang dilakukan dalam siklus II ini relatif sama dengan perencanaan dan pelaksanaan dalam siklus I, namun ada beberapa langkah kemungkinan dilakukan perbaikan dan penyempurnaan tindakan sesuai dengan kenyataan yang ditemukan di lapangan. Adapun rincian kegiatannya adalah sebagai berikut: (1) Merumuskan tindakan selanjutnya berdasarkan hasil refleksi siklus I, yaitu menyusun rencana baru untuk tindak lanjuti, antara lain mengawasi siswa lebih tegas lagi dan memberikan arahan atau motivasi kepada siswa yang 
kurang memperhatikan pelajaran atau tidak aktif; (2) Melaksanakan siklus II; (3) Siswa diberi tes; dan (4) Analisis hasil pemantauan siklus II.

\section{Indikator Keberhasilan}

Kriteria dan ukuran keberhasilan tindakan kelas yang digunakan dalam penelitian ini mengacu pada kurikulum yang berlaku sekarang. Dalam hal ini siswa dikatakan telah tuntas apabila telah mencapai nilai 70 dari skor ideal dan dikatakan tuntas secara klasikal jika mencapai $70 \%$ dari jumlah siswa yang tuntas belajar. Indikator keberhasilan untuk aktivitas guru dikatakan berhasil apabila interprestasi kriteria tindakan berada pada interval skor $60 \%<$ $K T \leq 80 \%$ dengan interpretasi "baik".

Tabel 1. Interpretasi Kriteria Keberhasilan Aktivitas Guru

\begin{tabular}{ccc}
\hline No & Interval Skor & Interpretasi \\
\hline 1 & $80 \%<K T \leq 100 \%$ & Baik Sekali \\
\hline 2 & $60 \%<K T \leq 80 \%$ & Baik \\
\hline 3 & $40 \%<K T \leq 60 \%$ & Cukup \\
\hline 4 & $20 \%<K T \leq 40 \%$ & Kurang \\
\hline 5 & $0 \%<K T \leq 20 \%$ & Sangat Kurang \\
\hline
\end{tabular}

Sedangkan indikator keberhasilan untuk aktivitas siswa dikatakan berhasil apabila interpretasi kriteria keberhasilan tindakan berada pada interval skor $60 \%<K T \leq 80 \%$ dengan interpretasi "baik".

Tabel 2. Interpretasi Kriteria Keberhasilan Aktivitas Siswa

\begin{tabular}{ccc}
\hline No & Interval Skor & Interpretasi \\
\hline 1 & $80 \%<K T \leq 100 \%$ & Aktif Sekali \\
\hline 2 & $60 \%<K T \leq 80 \%$ & Aktif \\
\hline 3 & $40 \%<K T \leq 60 \%$ & Cukup \\
\hline 4 & $20 \%<K T \leq 40 \%$ & Kurang \\
\hline 5 & $0 \%<K T \leq 20 \%$ & Sangat Kurang \\
\hline
\end{tabular}

\section{Hasil Penelitian}

\section{Siklus 1}

Siklus I dilaksanakan selama 3 kali pertemuan dengan 2 kali proses pembelajaran materi dan 1 kali pertemuan tes siklus I dengan tahapan pelaksanaan sebagai berikut:

Tahap Perencanaan, terlebih dahulu peneliti melakukan: (1) Konsultasi dengan dosen pembimbing dan guru mata pelajaran yang bersangkutan mengenai rencana teknis penelitian; (2) Menelaah kurikulum pada mata pelajaran matematika; (3) Membuat rancangan perangkat pembelajaran (RPP) untuk setiap pertemuaan; (4) Menyusun lembar observasi siswa untuk mengamati dan mengidentifikasi segala yang terjadi selama proses belajar mengajar berlangsung; (5) Menyusun lembar observasi aktivitas guru dalam mengelola pembelajaran matematika dengan menerapkan model kooperatif; (6) Membuat alat evaluasi tes hasil belajar siswa untuk melihat kemampuan siswa dalam menyelesaikan soal-soal yang berdasarkan materi yang telah diberikan;dan (7) Membuat kunci jawaban soal evaluasi akhir siklus.

Tahap pelaksanaan pada pada siklus I dilaksanakan selama 3 kali pertemuan. Pertemuan pertama dan kedua yaitu pembelajaran dengan menggunakan penerapan model kooperatif, sedangkan pertemuan ketiga evaluasi belajar siswa pada siklus I. Pelaksanaan tindakan penelitian ini mengikuti langkah-langkah yaitu sebagai berikut: (1) Membuka pelajaran dan mengorganisasi kelas untuk belajar; (2) Menyampaikan kepada siswa tentang materi pokok, 
kompetensi dasar, dan tujuan pembelajaran yang akan diterapkan untuk menyelesaikan masalah konstektual; (3) Memotivasi siswa dengan mengaitkan materi yang akan dipelajari dengan kehiduapan siswa sehari-hari; (4) Menyajikan informasi tentang materi yang akan dipelajari siswa dengan mengaitkan masalah konstektual; (5) Membentuk kelompok besar beserta memilih pemimpin dari kelompok besar tersebut; (6) Setelah kelompok besar terbentuk kemudian dilanjutkan dengan pemecahan kelompok besar menjadi beberapa kelompok kecil; (7) Memberikan reward (Penghargaan).

Adapun hasil rekapitulasi tes hasil belajar matematika pada siklus I dapat dilihat pada tabel yan menunjukkan bahwa: hasil belajar matematika pada tes siklus I dengan nilai rata-rata $(65,29)$, standar deviasi sebesar $(12,99)$, variansi sebesar $(168,74)$, rentang skor sebesar $(45)$, sedangkan skor minimum (45), skor maksimum (90), dan jumlah skor keseluruhan dari 31 siswa yaitu (2024). Jika nilai rata-rata disesuaikan dengan tabel pengkategorian hasil belajar maka secara umum hasil belajar matematika siswa pada siklus I dapat dikatakan rendah. Hal ini terlihat dari pencapaian rata-rata yang masih dibawah KKM yang ditetapkan di sekolah.

Tabel 3. Statistik Deskriptif Hasil Belajar Matematika Siswa Siklus I

\begin{tabular}{lc}
\hline \multicolumn{1}{c}{ Statistik } & Nilai Statistik \\
\hline Jumlah Sampel & 31 \\
\hline Rata-Rata & 65,29 (Rendah) \\
\hline Median & 60,00 \\
\hline Modus & 60 \\
\hline Standar Deviasi & 12,99 \\
\hline Variansi & 168,74 \\
\hline Rentang Skor & 45 \\
\hline Skor Minimum & 45 \\
\hline Skor Maksimum & 90 \\
\hline
\end{tabular}

Jika skor tes kemampuan hasil belajar siswa pada tes akhir siklus I dikelompokkan kedalam lima kategori maka diperoleh tabel distribusi frekuensi dan persentase sebagai berikut:

Tabel 4. Perolehan Persentase Kategorisasi Tes Siklus I

\begin{tabular}{|c|c|c|c|}
\hline Skor & Kategori & Frekuensi & Persentase $(\%)$ \\
\hline $90-100$ & Sangat Tinggi & 1 & $3 \%$ \\
\hline $80-89$ & Tinggi & 4 & $13 \%$ \\
\hline $70-79$ & Cukup & 8 & $26 \%$ \\
\hline $60-69$ & Rendah & 10 & $32 \%$ \\
\hline $0-59$ & Sangat Rendah & 8 & $26 \%$ \\
\hline \multicolumn{2}{|c|}{ Jumlah } & 31 & $100 \%$ \\
\hline
\end{tabular}

Berdasarkan tabel diatas diperoleh bahwa terdapat 8 siswa berada pada kategori Sangat Rendah (SR) dengan persentase $26 \%$, sebanyak 10 siswa berada pada kategori Rendah (R) dengan persentase $32 \%$, sebanyak 8 siswa berada pada kategori Cukup (C) dengan persentase $26 \%$, sebanyak 4 siswa berada pada kategori Tinggi (T) dengan persentase 13\%, dan hanya ada 1 siswa yang berada dalam kategori Sangat Tinggi (ST) dengan persentase $3 \%$. 
Jika dikaitkan dengan kriteria ketuntasan hasil belajar, maka hasil belajar siswa pada tes Siklus I dapat dikelompokkan kedalam dua kategori sehingga diperoleh skor frekuensi dan persentase yang ditunjukkan pada tabel berikut ini:

Tabel 5. Distribusi Frekuensi dan Persentase Tes Siklus I

\begin{tabular}{|c|c|c|c|c|}
\hline No. & Skor & Kategori & Frekuensi & Persentase (\%) \\
\hline 1 & $<70$ & Tidak Tuntas & 18 & $58 \%$ \\
\hline 2 & $\geq 70$ & Tuntas & 13 & $42 \%$ \\
\hline \multicolumn{3}{|c|}{ Jumlah } & 31 & $100 \%$ \\
\hline
\end{tabular}

Berdasarkan tabel 4.22 terlihat bahwa persentase hasil belajar siswa setelah diterapkan model kooperatif pada siklus I sebesar 58\% dalam kategori tidak tuntas dan $42 \%$ dalam kategori tuntas. Adapun ketuntasan belajar siswa secara klasikal berada pada interval $<70 \%$ dengan kategori sangat rendah. Ini berarti setelah dilakukan penerapan model kooperatif untuk meningkatkan hasil belajar matematika siswa pada siklus I belum mencapai ketuntasan klasikal. Oleh karena itu penulis melanjutkan kesiklus II.

Tahap Observasi, dilakukan pada saat proses belajar mengajar sedang berlangsung. Kegiatan Observasi terhadap aktivitas guru dibantu oleh seorang observer untuk mempermudah agar penelitian lebih objektif. Hasil yang diperoleh adalah rata-rata persentase aktivitas guru pada siklus I dengan penerapan model kooperatif yaitu 82\%. Berdasarkan kriteria keberhasilan tindakan, aktivitas guru ini tergolong kategori "baik sekali" dengan interval skor $80 \%<\mathrm{KT} \leq$ $100 \%$. Sedangkan, hasil observasi aktivitas siswa pertemuan pertama pada siklus I diperoleh hasil dengan penerapan model kooperatif berdasarkan indikator perhatian siswa diperoleh ratarata $(2,19)$ dengan persentase $54,8 \%$ sehingga kriteria keberhasilan tindakan aktivitas siswa ini tergolong kategori "cukup" dengan interval skor $40 \%<\mathrm{KT} \leq 60 \%$, partisispasi siswa diperoleh rata-rata $(2,65)$ dengan persentase $66,1 \%$, pemahaman siswa diperoleh rata-rata $(2,55)$ dengan persentase $63,7 \%$ termasuk kategori "aktif", kerja sama diperoleh rata-rata $(2,68)$ dengan persentase $66,9 \%$ termasuk kategori "aktif".

Sedangkan pertemuan kedua pada siklus I indikator perhatian siswa diperoleh rata-rata $(2,74)$ dengan persentase $68,5 \%$ sehingga kriteria keberhasilan tindakan aktivitas siswa ini tergolong kategori "aktif" dengan interval skor $60 \%<\mathrm{KT} \leq 80 \%$, partisispasi siswa diperoleh rata-rata $(2,77)$ dengan persentase $69,4 \%$, pemahaman siswa diperoleh rata-rata $(2,84)$ dengan persentase $71 \%$ termasuk kategori "aktif", kerja sama diperoleh rata-rata $(2,9)$ dengan persentase $73 \%$ termasuk kategori "aktif".

Tahap Refleksi diperoleh beberapa kekurangan, yakni: (1) siswa kurang bersemangat saat diajarkan dengan model kooperatif dikarenakan pada saat pembagian kelompok kecil tidak seimbang mengakibatkan terdapat kelompok yang anggotanya terdiri dari orang-orang yang tidak tahu apa-apa; (2) guru kurang menciptakan suasana belajar yang baik sehingga siswa kurang bersemangat dalam proses pembelajaran; dan (3) siswa mengalami tingkat kesulitan yang berbeda saat menyelesaikan masalah SPLDV. Misalnya soal nomor 2 dan 3 memiliki tingkat kesulitan sehingga kebanyakan siswa menjawab benar. Hal itu dapat dilihat pada salah satu jawaban siswa pada gambar berikut :

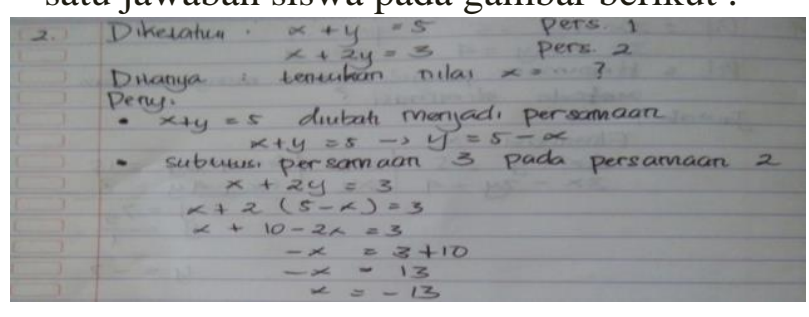

Soal 2

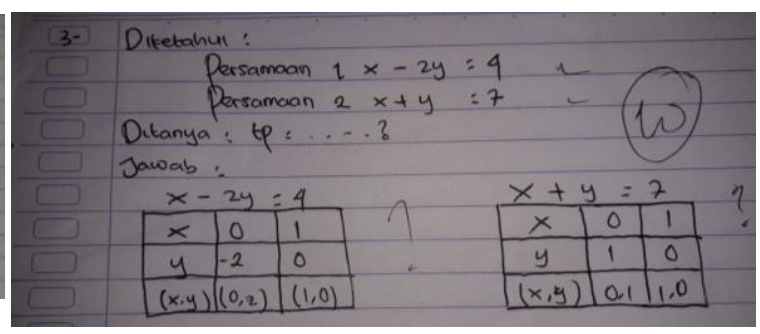

Soal 3

Gambar 1. Kesulitan yang dihadapi siswa saat menyelesaikan soal SPLDV 

berikut :

Perbaikan-perbaikan dari kekurangan siklus I untuk diterapkan pada siklus II sebagai

1. Memberikan penghargaan berupa penambahan nilai hal ini dilakukan agar siswa lebih bersemangat dan antusias dalam bersaing dengan kelompok lain. Seperti pemberian tambahan pada kelompok yang aktif/kompak dalam menyelesaikan tugas dan menjawab dengan benar.

2. Guru membagi kelompok diskusi yang digunakan pada siklus II terdiri dari 2 kelompok besar tersebut akan tetapi perbaikan terjadi pada kelompok kecil. Pada siklus I terdapat 3 kelompok kecil dengan anggotanya terdiri dari 5 siswa sedangkan pada siklus II ini, terdapat 5 kelompok kecil dengan anggotanya terdiri 3 siswa. Kemudian guru memberikan permasalahan yang berhubungan dalam kehidupan sehari-hari.

3. Mengatur waktu dan membagi setiap tugas untuk diselesaikan perindividu walaupun dalam proses pembelajaran dilakukan secara berkelompok. Hal ini dilakukan agar siswa dapat menyelesaikan soal tepat pada waktunya.

4. Mengubah posisi duduk siswa yang suka melakukan kegiatan lain pada saat proses belajar mengajar yang berada dibangku bagian belakang kebangku bagian depan agar siswa tersebut selalu menjadi perhatian guru dan tidak leluasa melakukan kegiatan lain saat penyajian informasi oleh guru.

\section{Siklus II}

Siklus II dilaksanakan selama 3 kali pertemuan, dengan 2 kali tatap muka dan 1 kali evaluasi dipertemuaan akhir siklus. Kegiatan siklus ini adalah mengulang kembali kegiatankegiatan yang telah dilaksanakan pada siklus I dengan melakukan perbaikan-perbaikan yang masih dianggap kurang pada siklus pertama atau siklus I.

Tahap Perencanaan, Pada siklus kedua ini tahap perencanaan hampir sama dengan tahap perencanaan dengan siklus I. Tahap Pelaksanaan adalah mengulangi langkah kerja pada siklus I. Tindakan-tindakan pada siklus II lebih dikembangkan dan didasari oleh hasil observasi dan refleksi pada siklus I. Adapun lanjutan tindakan tersebut dilakukan dengan melaksanakan tindakan berdasarkan rencana pembelajaran yang telah disiapkan. Pada setiap pertemuan, guru menjelaskan materi sesuai dengan rencana pembelajaran pada pertemuan yang bersangkutan disertai dengan contoh soal serta ilustrasi yang melibtkan siswa. Selanjutnya guru membagikan tugas kepada masing-masing kelompok dengan jumlah yang lebih sedikit tetapi tetap terdapat setiap indikator pembelajaran. Setelah itu siswa mengerjakannya, kemudian tugas tersebut dipresentasikan. Pada tahap siklus II menggunakan langkah-langkah yang sama dengan dilakukan pada siklus I. Setelah pertemuan keempat dan pertemuan kelima dilaksanakan selanjutnya dilaksanakan tes siklus II pada pertemuan keenam.

Adapun hasil rekapitulasi tes hasil belajar matematika siswa untuk tes siklus II dapat dilihat pada tabel berikut :

Tabel 6. Statistik Deskriptif Tes Hasil Belajar Matematika Siswa Siklus II

\begin{tabular}{cc}
\hline Statistik & Nilai Statistik \\
\hline Jumlah Sampel & 31 \\
\hline Rata-Rata & 82,48 (Tinggi) \\
\hline Median & 83,00 \\
\hline Modus & 76 \\
\hline Standar Deviasi & 8,29 \\
\hline
\end{tabular}


Volume 1, No 1, Juni 2021, pp. 22-33

\begin{tabular}{cc}
\hline Variansi & 68,72 \\
\hline Rentang Skor & 33 \\
\hline Skor Minimum & 63 \\
\hline Skor Maksimum & 96 \\
\hline
\end{tabular}

Berdasarkan tabel 4.24 menunjukkan bahwa hasil belajar matematika pada tes siklus I dengan nilai rata-rata $(82,48)$, standar deviasi sebesar $(8,29)$, variansi sebesar $(68,72)$, rentang skor sebesar (33), sedangkan skor minimum (63), skor maksimum (96), dan jumlah skor keseluruhan dari 31 siswa yaitu (2553). Jika skor tes kemampuan hasil belajar siswa pada tes akhir siklus II maka diperoleh tabel distribusi frekuensi dan persentase sebgai berikut:

Tabel 6. Perolehan Persentase Kategorisasi Tes Siklus II

\begin{tabular}{|c|c|c|c|}
\hline Skor & Kategori & Frekuensi & Persentase (\%) \\
\hline $90-100$ & Sangat Tinggi & 8 & $26 \%$ \\
\hline $80-89$ & Tinggi & 13 & $42 \%$ \\
\hline $70-79$ & Cukup & 7 & $23 \%$ \\
\hline $60-69$ & Rendah & 3 & $9 \%$ \\
\hline $0-59$ & Sangat Rendah & 0 & $0 \%$ \\
\hline \multicolumn{2}{|c|}{ Jumlah } & 31 & $100 \%$ \\
\hline
\end{tabular}

Berdasarkan tabel diatas diperoleh bahwa tidak ada siswa berada pada kategori Sangat Rendah (SR), sebanyak 3 siswa berada pada kategori Rendah (R) dengan persentase 9\%, sebanyak 7 siswa berada pada kategori Cukup (C) dengan persentase 23\%, sebanyak 13 siswa berada pada kategori Tinggi (T) dengan persentase $42 \%$, dan terdapat 8 siswa yang berada dalam kategori Sangat Tinggi (ST) dengan persentase $26 \%$.

Jika dikaitkan dengan kriteria ketuntasan hasil belajar, maka hasil belajar siswa pada tes siklus II dapat dikelompokkan kedalam dua kategori sehingga diperoleh skor frekuensi dan persentase yang ditunjukkan pada tabel berikut ini :

Tabel 7. Distribusi Frekuensi Dan Persentase Tes Siklus II

\begin{tabular}{ccccc}
\hline No. & Skor & Kategori & Frekuensi & Persentase \\
\hline 1. & $<70$ & Tidak Tuntas & 3 & $9 \%$ \\
\hline 2. & $\geq 70$ & Tuntas & 28 & $91 \%$ \\
\hline & Jumlah & & 31 & $100 \%$ \\
\hline
\end{tabular}

Tahap Observasi, terjadi perubahan pada pelaksaanan peneliti yang bertindak sebagai guru. Perubahan tersebut diperoleh dari lembar observasi pada setiap pertemuan yang dicatat pada setiap siklus. Lembar observasi tersebut untuk mengetahui perubahan sikap siswa selama proses belajar mengajar berlangsung di kelas serta perubahan pelaksanaan kelas yang dilakukan guru. Berdasarkan kriteria keberhasilan tindakan, aktivitas guru ini tergolong kategori "baik sekali", sedangkan observasi aktivitas siswa pertemuan keempat pada siklus II diperoleh hasil dengan penerapan model kooperatif berdasarkan indikator perhatian siswa diperoleh rata-rata $(2,97)$ dengan persentase $74,2 \%$ sehingga kriteria keberhasilan tindakan aktivitas siswa ini tergolong kategori "aktif".

Tahap Refleksi Siklus II yang dilakukan peneliti pada siklus II setelah dikonsultasikan kepada guru mata pelajaran sebagai observer, maka pada siklus ini dilakukan perbaikanperbaikan pada bagian yang kurang maksimal dalam proses pembelajaran. Adapun hasil perbaikan-perbaikan dari siklus I sebagai berikut : (1) Aktivitas siswa mulai bersemangat dan antusias dalam proses pembelajaran.; (2) guru kembali melakukan pembagian kelompok. 
Kelompok diskusi dalam siklus II ini terdiri dari 2 kelompok besar kemudian dipecah menjadi 5 kelompok kecil yang beranggota 3 siswa serta guru membagi kelompok dengan merata. Jadi dalam kelompok kecil tersebut sudah tidak terdapat lagi siswa yang tidak tahu apa-apa. Serta guru memberikan penghargaan berupa penambahan nilai sehingga siswa bersemangat dan antusias dalam proses pembelajaran

\section{Diskusi}

Penelitian tindakan kelas ini dilaksanakan dalam 2 siklus. Tiap siklus dilaksanakan sesuai dengan indikator keberhasilan yang ingin dicapai. Siklus I dilaksanakan selama 3 kali pertemuan, dimana 2 kali pertemuan digunakan sebagai proses pembelajaran dan 1 kali pertemuan dilakukan tes pada akhir siklus I. Sedangkan siklus II merupakan pelaksanaan perbaikan dari kekurangan siklus I. Dari kedua siklus terjadi perubahan yang signifikan mulai dari aktivitas guru dan siswa semakin aktif hingga pengetahuan siswa dalam menyelesaikan masalah SPLDV semakin baik. Secara khusus, kami akan membahas penyebab meningkatnya pengetahuan siswa. Dimana secara umum, terdapat pengaruh pembelajaran yang mengakibatkan pengetahuan siswa ikut meningkat (Harel, 2017).

Dari hasil penelitian, kami menemukan bahwa pengetahuan siswa tentang SPLDV pada Siklus I berada pada kategori rendah . Hal itu disebabkan karena siswa hanya paham akan satu variabel saja. Ini menunjukkan bahwa pemikiran siswa dipengaruhi oleh masalah atau materi yang dipelajari sebelumnya (Kamber \& Takaci, 2018; Mcgowen \& Tall, 2010). Sehingga mempengaruhi pemikiran siswa saat menghadapi situasi baru. Selain itu, siswa mengalami keterbatasan informasi tentang makna variabel. Hal ini disebabkan oleh kefamiliaran siswa terhadap variabel $x$ dan mengabaikan variabel lainnya. Ini menunjukkan permasalahan tersendiri bagi siswa pada siklus awal, sehingga pada siklus berikutnya kami mengupayakan untuk memahamkan makna variabel bagi siswa.

Masalah lain yang ditemukan saat siswa diajarkan dengan model kooperatif untuk materi SPLDV adalah siswa kebingungan memecahkan masalah dengan menggunakan metode grafik, substitusi, dan eliminasi. Dalam hal ini, siswa tidak memahami penggunaan ketiga metode penyelesaian. Situasi ini sejalan dengan temuan Yau \& Mok (2016) bahwa masalah tersebut dipengaruhi ketidakfamilaran siswa pada situasi yang melibatkan dua variabel.

Sebagai penutup, kami menyoroti pengaruh model koopertaif yang berpengaruh pada peningkatan pengetahuan siswa pada materi SPLDV. Kegiatan siklus II adalah mengulang kembali kegiatan-kegiatan yang telah dilaksanakan pada siklus I dengan melakukan perbaikanperbaikan yang masih dianggap kurang pada siklus I. Perbaikan pada siklus I terjadi pada fase kedua yaitu mengorganisasikan siswa kedalam kelompok-kelompok belajar. Pada siklus I kekurangannya ialah terlalu banyaknya anggota dalam satu kelompok kecil sehingga siswa kurang aktif dalam menyelesaikan permasalahan yang diberikan serta kurangnya kerjasama dalam diskusi kecil. Oleh karena itu, berdasarkan hasil penelitian tersebut maka dapat disimpulkan bahwa melalui model kooperatif dapat meningkatnya pengetahuan siswa tentan SPLDV.

\section{Simpulan}

Berdasarkan hasil dan pembahasan diatas, dapat disimpulkan bahwa terjadi peningkatan pengetahuan siswa tentang SPLDV melalui model kooperatif. Lebih lanjut, peningkatan ini berdampak pada peningkatan aktivitas guru dan siswa dalam kelas serta meminimalkan kesalahan siswa dalam menyelesaikan masalah SPLD. Dari hasil penelitian, kami menyarankan bahwa dalam penelitian tindakan perlu juga mengambil data kualitatif siswa terkait materi agar data yang dihasilkan lebih kaya dan mendalam. Selanjutnya, kami 
menyarankan agar pembelajaran kooperatif hendaknya digunakan sebagai alternatif model pembelajaran untuk meningkatkan pengetahuan siswa dalam matematika. Terakhir, kami merekomendasikan untuk menelusuri kembali siswa yang secara konsisten menunjukkan kegagalannnya dalam memahami konsep SPLDV secara detail.

\section{Konflik Kepentingan}

Penulis menyatakan tidak ada konflik kepentingan

\section{Referensi}

Blanton, M., Otálora, Y., Brizuela, B. M., Gardiner, A. M., Sawrey, K. B., Gibbins, A., \& Kim, Y. (2018). Exploring Kindergarten Students' Early Understandings of the Equal Sign. Mathematical Thinking and Learning, 20(3), 167201. https://doi.org/10.1080/10986065.2018.1474534

Filloy, E., Rojano, T., \& Solares, A. (2010). Problems Dealing With Unknown Quantities and Two Different Levels of Representing Unknowns. Journal for Research in Mathematics Education, 41(1), 52-80. https://doi.org/10.2307/40539364

Fonger, N. L. (2019). Meaningfulness in representational fluency: An analytic lens for students' creations, interpretations, and connections. Journal of Mathematical Behavior, October, 1-26. https://doi.org/10.1016/j.jmathb.2018.10.003

Harel, G. (2017). The learning and teaching of linear algebra: Observations and generalizations. Journal of Mathematical Behavior, 46, 69-95.https://doi.org/10.1016/.j.jmathb.2017.02.007

Hewitt, D. (2012). Young students learning formal algebraic notation and solving linear equations: Are commonly experienced difficulties avoidable? Educational Studies in Mathematics, 81(2), 139-159. https://doi.org/10.1007/s10649-012-9394-x

Kamber, D., \& Takaci, D. (2018). On problematic aspects in learning trigonometry. International Journal of Mathematical Education in Science and Technology, 49(2), 161175. https://doi.org/10.1080/0020739X.2017.1357846

Lima, R. N. De, \& Tall, D. (2008). Procedural embodiment and magic in linear equations. May 2007, 3-18. https://doi.org/10.1007/s10649-007-9086-0

Mcgowen, M. A., \& Tall, D. O. (2010). Metaphor or Met-Before ? The effects of previouos experience on practice and theory of learning mathematics. Journal of Mathematical Behavior, 29(3), 169-179. https://doi.org/10.1016/j.jmathb.2010.08.002

Soneira, C., González-Calero, J. A., \& Arnau, D. (2018). An assessment of the sources of the reversal error through classic and new variables. Educational Studies in Mathematics, 99(1), 43-56. https://doi.org/10.1007/s10649-018-9828-1

Tall, D., de Lima, R. N., \& Healy, L. (2014). Evolving a three-world framework for solving algebraic equations in the light of what a student has met before. Journal of Mathematical Behavior, 34, 1-13. https://doi.org/10.1016/j.jmathb.2013.12.003 
Wilkie, K. J. (2016). Students' use of variables and multiple representations in generalizing functional relationships prior to secondary school. Educational Studies in Mathematics, 93(3), 333-361. https://doi.org/10.1007/s10649-016-9703-x

Yau, K. W., \& Mok, I. A. C. (2016). Insights from students' private work in their notebooks: how do students learn from the teacher's examples? Educational Studies in Mathematics, 93(3), 275-292. https://doi.org/10.1007/s10649-016-9702-y 